\title{
The coupling of oligotrich ciliate populations and hydrography in the East China Sea: spatial and temporal variations
}

\author{
Kuo-Ping Chiang ${ }^{\mathrm{a}, *}$, Chiu-Yi Lin ${ }^{\mathrm{a}}$, Chung-Hsien Lee ${ }^{\mathrm{a}}$, Fuh-Kwo Shiah ${ }^{\mathrm{b}}$, \\ Jeng Chang ${ }^{\mathrm{c}}$ \\ ${ }^{a}$ Institute of Environmental Biology and Fisheries Science, National Taiwan Ocean University, Keellung 202-204, Taiwan, ROC \\ ${ }^{\mathrm{b}}$ Institute of Oceanography, National Taiwan University, P.O. Box 23-13, Taipei, Taiwan, ROC \\ ${ }^{\mathrm{c}}$ Institute of Marine Biology, National Taiwan Ocean University, Keellung 202-24, Taiwan, ROC
}

Accepted 16 December 2002

\begin{abstract}
Variations in the spatial and temporal distribution of oligotrich ciliate populations in the East China Sea were investigated during four cruises of the R/V Ocean Researcher I between December 1997 and October 1998. Over the entire continental shelf, a seasonal cycle was found with a distinct 3-5-fold increase in the abundance of oligotrich ciliates in summer. This increase appeared to be induced by the tremendous summertime runoff from the Changjiang. A radial-type spatial distribution pattern also was observed in summer, with population densities higher toward the Changjiang plume but highest of all in the margins of the plume. In spring and fall, the spatial distribution of the oligotrich ciliates was closely correlated to the abundance of cyanobacterium Synechococcus. In summer in the plume region, mixotrophic ciliates accounted for over $50 \%$ of the total ciliate population, compared to less than $30 \%$ outside the plume or that in other seasons. We propose a model in which these ciliates constitute part of the pathway through which the particulate and dissolved organic carbon in the runoff water is incorporated into the oceanic food web.

(C) 2003 Elsevier Science Ltd. All rights reserved.
\end{abstract}

\section{Introduction}

For some years now, researchers have recognized that bacteria and protists play essential roles in marine pelagic ecosystems (Pomeroy, 1974). Planktonic ciliates are an important component in the microbial food chain, which is also referred to as the microbial loop (Azam et al., 1983), and they may help bring about trophic flux and nutrient

\footnotetext{
*Corresponding author. Fax: +886-2-2462-1016.

E-mail address: kpchiang@mail.ntou.edu.tw (K.-P. Chiang).
}

cycling (Laybourn-Parry, 1992). In a typical oligotrophic oceanic ecosystem, organic exudates, or dissolved organic carbon (DOC), from phytoplankton are used by bacteria, and these, in turn, are consumed by protistan predators, such as planktonic microflagellates (Fenchel, 1982; Sherr et al., 1991) and ciliates (Sherr and Sherr, 1987; Fenchel and Jonsson, 1988). Such picoautotrophs as Prochlorococcus and Synechococcous similarly make a significant contribution to phytoplankton biomass and productivity in marine ecosystems (Stockner and Antia, 1986; Shiomoto et al., 1997). Typically, in the subtropical shelf water of the East 
China Sea (ECS), picophytoplankton comprise $25-86 \%$ of all chlorophyll $a$ and $19-72 \%$ of primary production (Chen, 2000; Chiang et al., 2002). However, picophytoplankton are too small to be effectively utilized by metazoan grazers. Picophytoplankton have to be repacked via the microbial food chain before their production can enter the grazing food chain (Marshall, 1973).

The ECS, the largest marginal sea in the western North Pacific, is a vast area of shallow water into which flows the tremendous river runoff from the Changjiang (Yangtze River; see Fig. 1). With an annual mean of about $3 \times 10^{3} \mathrm{~m}^{3} \mathrm{~s}^{-1}$, water discharge reaches its maximum in summer (Beardsley et al., 1985). The fact that phytoplankton productivity is less than likely sufficient to support the demand made by bacteria in the shelf area of the ECS has led Shiah et al. (2000) to suggest that the substantial shortfall is made up by non-phytoplanktonic, allochothonous sources. The discharged fresh river water, therefore, might, ultimately affect the spatial and temporal patterns of the ciliate populations and, as a consequence, the microbial food web in these shelf waters. New highly supportive evidence for this theory is presented in this paper.

Oligotrich ciliates are known to be a major component of ciliate community in the ECS (Ota and Taniguchi, 2003). For the first time, their spatial and temporal variations are examined in the study, and the relationships between ciliate population density and surface salinity, particulate organic carbon (POC), and bacterial productivity (BP) in summer were analyzed. Besides these, this study discusses variations in the population of mixotrophic ciliates (MC) and the standing stock of cyanobacteria.

\section{Materials and methods}

During four cruises of the R/V Ocean Researcher I in December (winter) 1997, and March (spring), June (summer), and October (fall) 1998, surface temperatures and salinity were measured at a total of 31-36 sampling stations along seven cross-shelf transects (Fig. 1). Water samples were collected at 16-22 sampling stations along four of

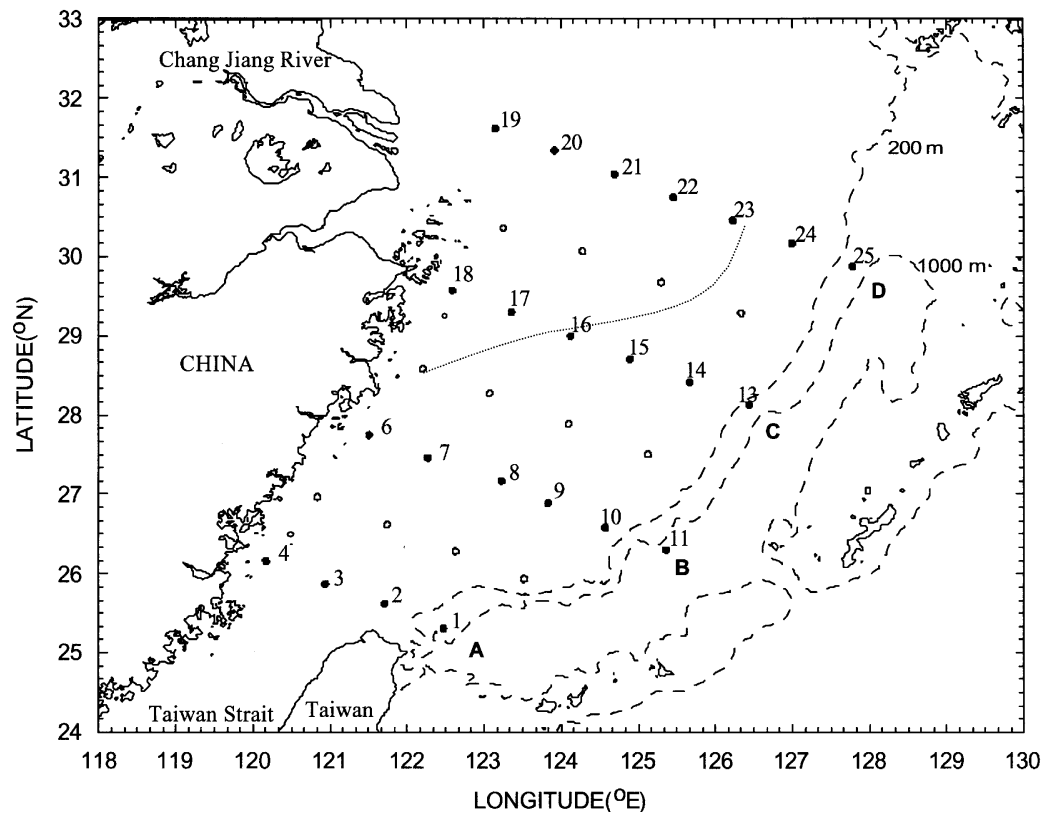

Fig. 1. ECS survey stations were located along seven cross-shelf transects (white and dark circles) on the four sampling cruises of 1997 and 1998. Dark circles indicate the stations where water samples were collected for the present study. Dashed lines indicate the Changjiang plume margin. 
the cross-shelf transects, indicated as Transects A, B, C and D (Fig. 1). A Sea Bird-General Oceanic Rosette assembly with 201 Go-Flo bottles were then employed to record temperature and salinity as well as to collect water samples from 5 to 11 different depths in the water column $(2 \mathrm{~m}$-bottom or $100 \mathrm{~m})$. The seawater samples were subsequently fixed in neutralized formalin ( $2 \%$ final concentration). To prevent degradation of the pigments in the plastids that had been ingested intact by the ciliates, the fixed samples were stored in a cool $\left(4^{\circ} \mathrm{C}\right)$, dark place until they could be examined under microscope.

Oligotrich ciliate cells in a $100-\mathrm{ml}$ sample were concentrated following the Utermöhl method and were identified and thoroughly counted in each sample using an inverted epifluorescence microscope (Nikon-Tmd 300) at $200 \times$ or $400 \times$ (Hasle, 1978). All of the oligotrich ciliates were classified as heterotrophic ciliates (HC) or MC based on their autofluorescence. Plastids that had been retained intact by the mixotrophic oligotrich ciliates were recognizable by red fluorescence they emitted when excited with light at $450-490 \mathrm{~nm}$ (blue light).

Next, water samples (0.5-2.01) for POC measurements were first filtered through a $200 \mu \mathrm{m}$ mesh to remove zooplankton and then through a pre-combusted $\left(550^{\circ} \mathrm{C}\right) 25 \mathrm{~mm} \mathrm{GF} / \mathrm{F}$ filter for $1 \mathrm{~h}$ (pumping pressure $<100 \mathrm{~mm} \mathrm{Hg}$ ). The $\mathrm{GF} / \mathrm{F}$ filters were then wrapped in pre-combusted aluminum foil in the next stage, and stored at $-4^{\circ} \mathrm{C}$. After being dried and acid fumed, the POC concentrations were measured with a $\mathrm{CHN}$ analyzer (Fisons; NA1500). Finally, a one-way ANOVA was used for statistical analysis and these results were compared using the least significant difference (LSD) method.

\section{Results}

\subsection{Ciliate community}

In ECS, the cell size of the ciliate community showed a gradual decrease from inner to outer shelf in all seasons (Fig. 2). The mean cell size also showed significant seasonal variations, especially
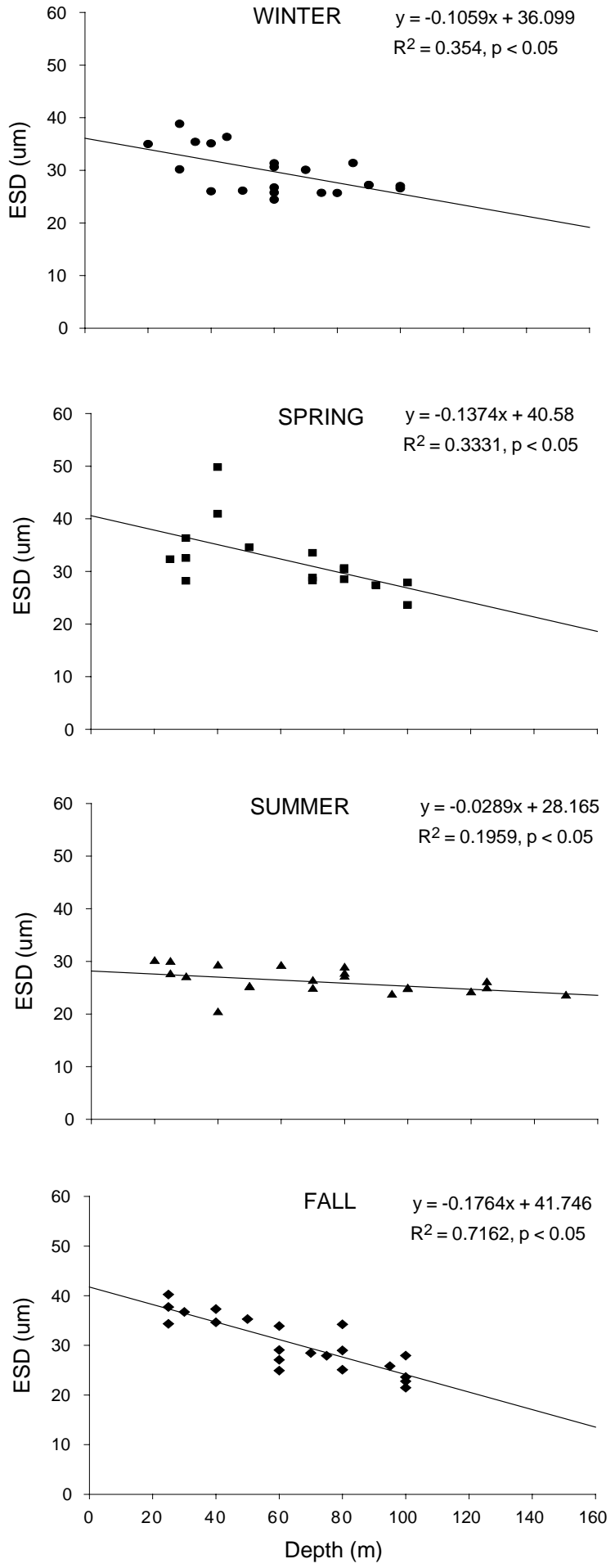

Fig. 2. The cross-shelf distribution of ESD of oligotrich ciliate in all four seasons in the ECS. 
in summer. The equivalent spherical diameter (ESD) in winter, spring, and fall were $29.6 \pm 0.93$, $32.1 \pm 1.51$, and $30.4 \pm 1.21 \mu \mathrm{m}$, respectively. In contrast, Summer ciliates had a smaller size at $26.1 \pm 0.52 \mu \mathrm{m}$ ESD $(P<0.05$, ANOVA and LSD analysis).

During the fall cruise, extra effort was made to obtain a general picture of species composition. On the basis of morphological characteristics, the ciliates were classified into three groups (Song et al., 1999): Strombilidiids, Tontonia in Strobilidiidae, and Strombilidiids species other than Tontonia. The most dominant component was Strombilidiids, making up $66.6 \% \pm 15.6 \%$, followed by other Strombilidiids at $31.2 \% \pm 14.7 \%$, and Tontonia at $2.1 \% \pm 2.7 \%$.

\subsection{Horizontal distribution}

In winter, spring and fall, the distributions pattern of surface salinity and temperature in the entire ECS ran roughly parallel to the coastline (Fig. 3), and salinity ranged between 32 and 34 psu at almost all stations. By contrast, during summer, a radial distribution pattern appeared in front of the mouth of the Changjiang, and in the center of the radial pattern, salinity was as low as $25 \mathrm{psu}$. The hydrographic features of the ECS, therefore, appeared to be significantly influenced by summer runoff from the Changjiang. It was also found that the extent and location of the plume closely approximated the typical Changjiang plume, as determined by Gong et al. (1996) in which they defined the temperature and salinity of the summer plume as $>23^{\circ} \mathrm{C}$ and $<31 \mathrm{psu}$, respectively. In the present paper, the plume is defined as $T=22-26^{\circ} \mathrm{C}$ and salinity as $<31 \mathrm{psu}$.

In the same vein, the horizontal density distribution of total oligotrich ciliates (TC) made pronounced seasonal change (Fig. 4). From winter to spring, relatively few $\left(1-50 \times 10^{4}\right.$ cells $\left.^{-3}\right)$ ciliates existed in the water column. Nevertheless, abundance tended to increase from the inner shelf to the outer shelf, with the maximum population density observed at the northeast outer shelf. Ciliate abundance increased in summer (30$180 \times 10^{4}$ cells $^{-3}$ ), distributed in a pattern that matched that of radial surface salinity, again with a high density $\left(>60 \times 10^{4}\right.$ cells $\left.\mathrm{m}^{-3}\right)$ area in the Changjiang plume $\left(<26^{\circ} \mathrm{C} ;<31 \mathrm{psu}\right)$. Then, in the fall, ciliate abundance generally decreased $\left(<20 \times 10^{4}\right.$ cells $^{-3}$ at most sampling stations), but a high ciliate abundance was still found in the center of the continental shelf $\left(>70 \times 10^{4}\right.$ cells $\mathrm{m}^{-3}$ ).

In winter, spring and fall, $\mathrm{HC}$ and $\mathrm{MC}$ had a similar distribution pattern to that of TC. HC were the most abundant components of the oligotrich ciliates, representing between $70.5 \%$ and $92.2 \%$ of the total number of oligotrich ciliates. In summer, MC abundance was high within the margin of the Changjiang plume $\left(>120 \times 10^{4}\right.$ cells $\left.^{-3}\right)$, where it accounted for $>50 \%$ of the total number compared to $<30 \%$ comprised outside the plume.

\subsection{Vertical distribution}

Water column profiles revealed very different patterns of vertical distribution of TC and MC between Kuroshio Water (St. 11), Shelf Mixing Water (St. 16), and the Changjiang plume (St. 19). In Kuroshio Water, the abundance of TC was, for the most part, uniform in the first $100 \mathrm{~m}$ and MC was rarely apparent in every season (Fig. 5). In the middle part of the continental shelf (shelf mixing water), a decrease in abundance was observed with depth and a subsurface ciliate maximum layer was observed in the bottom of euphotic zone (euphotic zone $=42 \mathrm{~m}$ ). MC was mostly evident in the euphotic zone in the fall and also had a maximum abundance at $40 \mathrm{~m}$. In summer, the abundance of TC was significantly higher than in other seasons in the Changjiang plume, and the vertical distribution pattern of TC differed considerably from that in other seasons. A maximum abundance of TC was observed at $2 \mathrm{~m}$, but TC then decreased with depth. A similar vertical profile to that of TC was observed in the case of MC, while the abundance ranged from $40-160 \times 10^{4}$ cells $\mathrm{m}^{-3}$, again being highest relative to that in other areas or seasons in the ECS.

\subsection{Seasonal variations}

Over the entire ECS, an annual pattern of surface salinity clearly emerged (Fig. 6A). In 

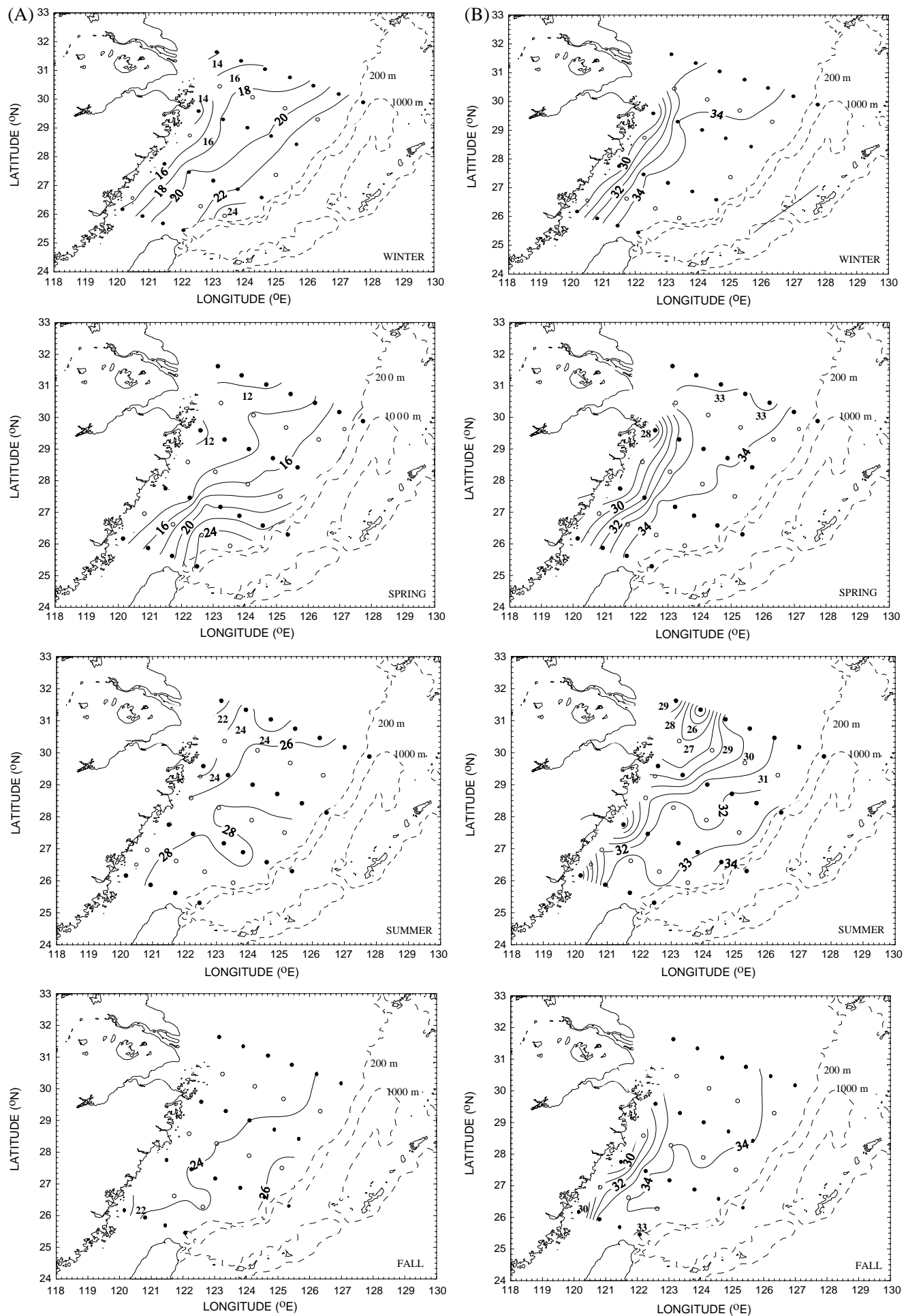

Fig. 3. Horizontal distribution of (A) surface temperature $\left({ }^{\circ} \mathrm{C}, 2 \mathrm{~m}\right.$ depth); and (B) salinity (psu) in all four season in the ECS. 
winter, spring and fall, the average surface salinity was greater than $33.0 \mathrm{psu}$, unlike that in summer when it was lower than $31.0 \mathrm{psu}$.

The fluctuations in depth-weighted average TC abundance from surface to bottom or $100 \mathrm{~m}$ were
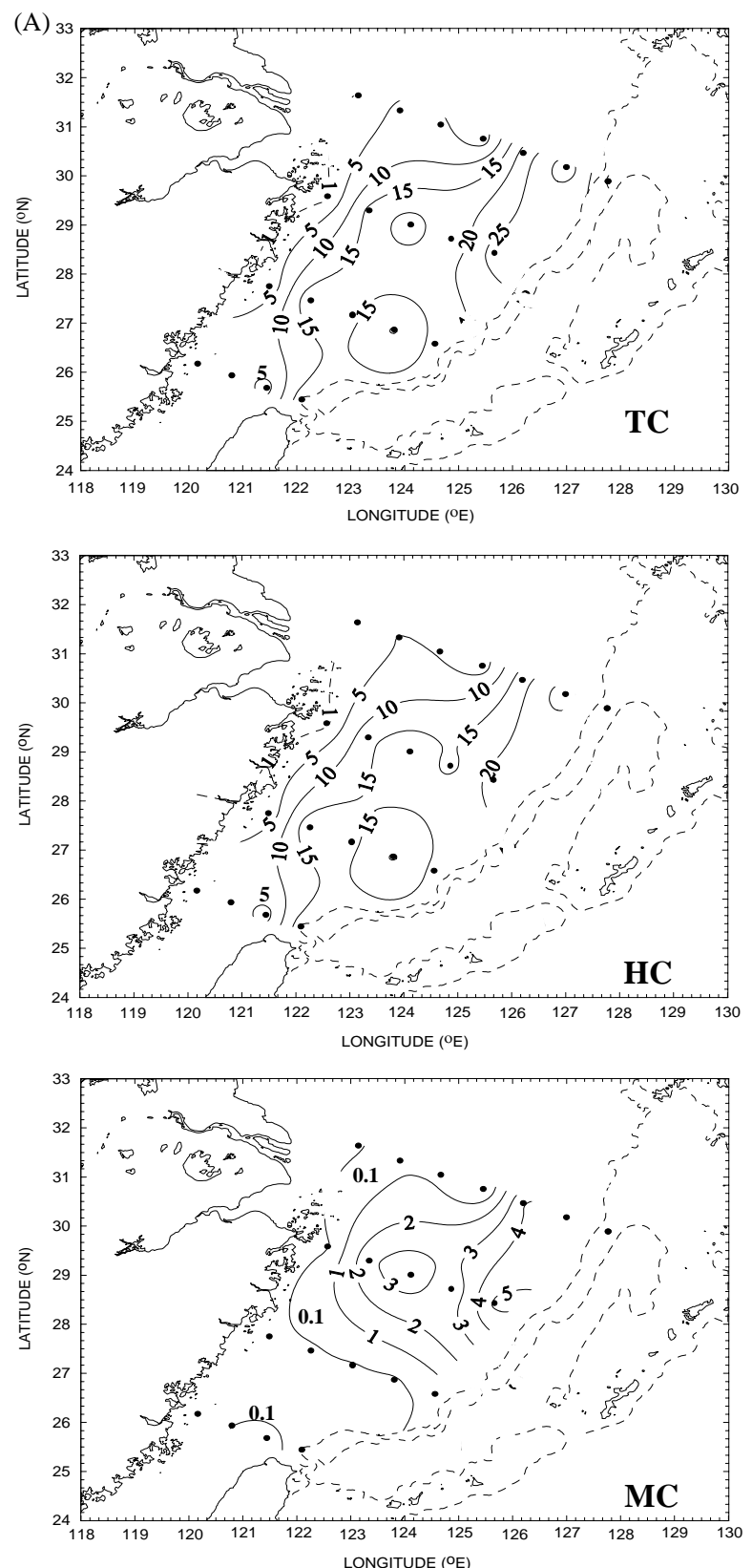

generally parallel to seasonal variations in surface salinity (Fig. 6A). A low standing stock of TC (11.41-18.43 $\times 10^{4}$ cells $\mathrm{m}^{-3}$ ) was observed during seasons of high salinity, namely winter, spring and fall, whereas the standing stock sharply increased
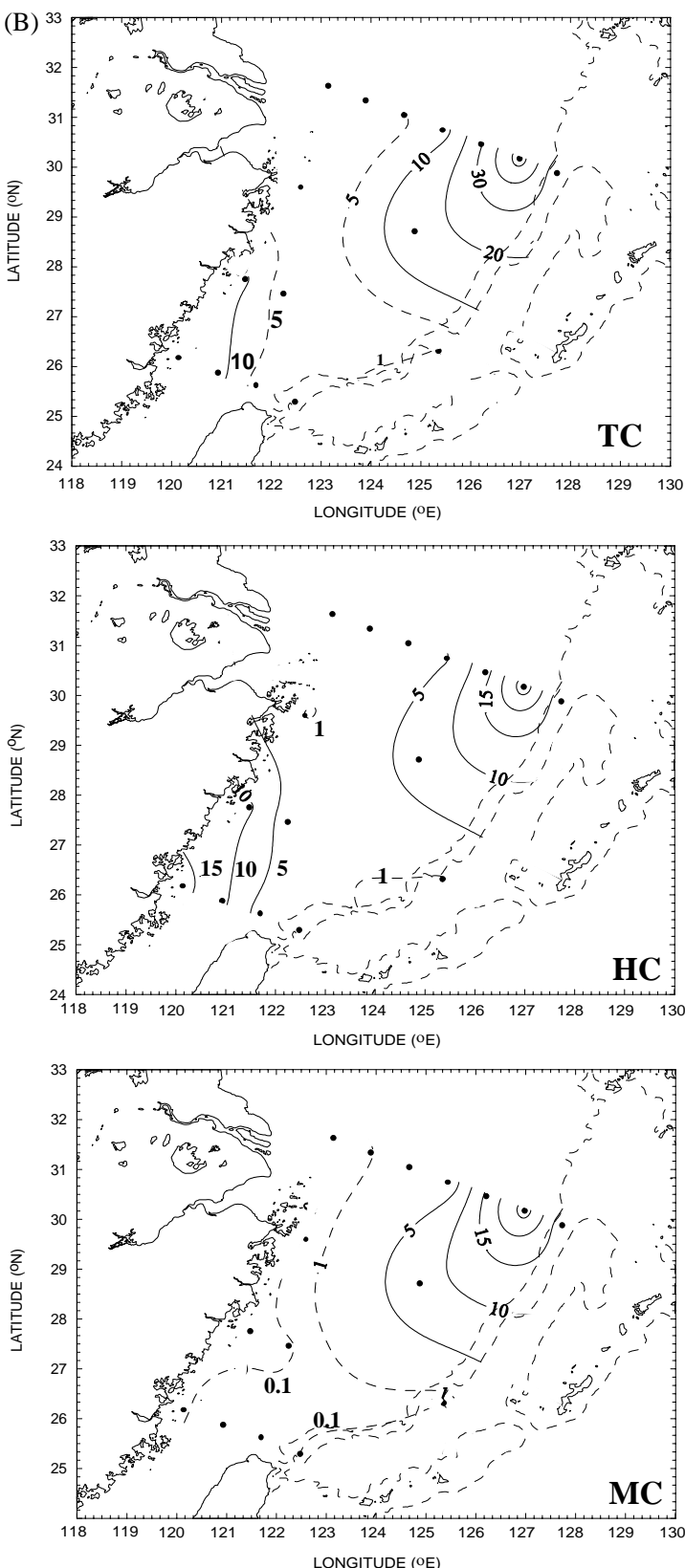

Fig. 4. Horizontal distribution of total ciliate (TC), heterotrophic ciliate $(\mathrm{HC})$ and mixotrophic ciliate $(\mathrm{MC})$ abundance $\left(\times 10^{4}\right.$ cells $\mathrm{m}^{-3}$ ) in the ECS in (A) winter (December 1997); (B) spring (March 1998); (C) summer (June 1998); and (D) fall (October 1998). 

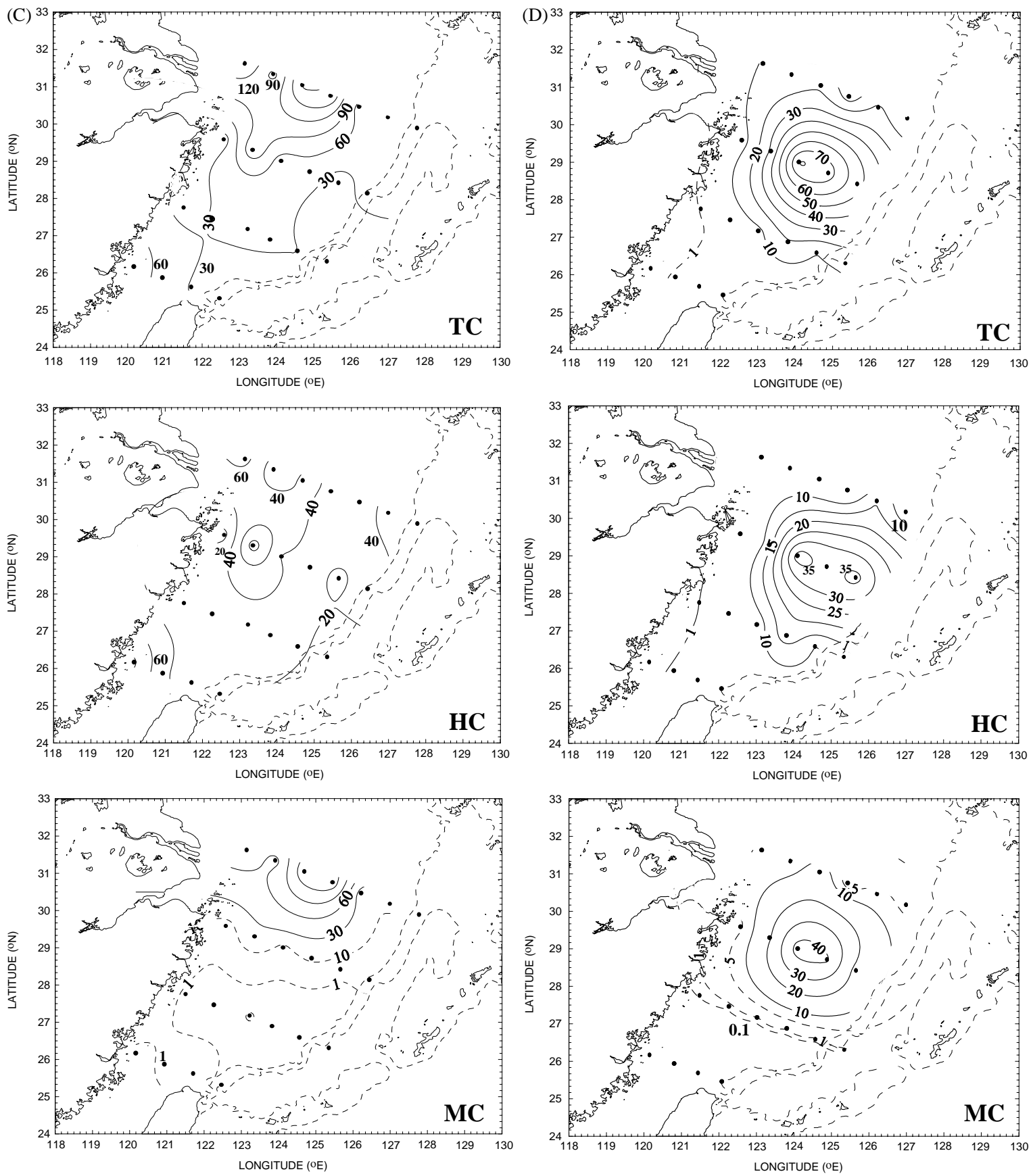

Fig. 4 (continued).

to $57.81 \times 10^{4}$ cells $\mathrm{m}^{-3}$, representing a $3-5$ fold difference, in the low salinity season (summer). Although similar patterns were also found for $\mathrm{HC}$ and MC (Fig. 7A), one-way ANOVA and LSD showed that seasonal density fluctuations were significant only for TC and HC $(P<0.05)$, but not 

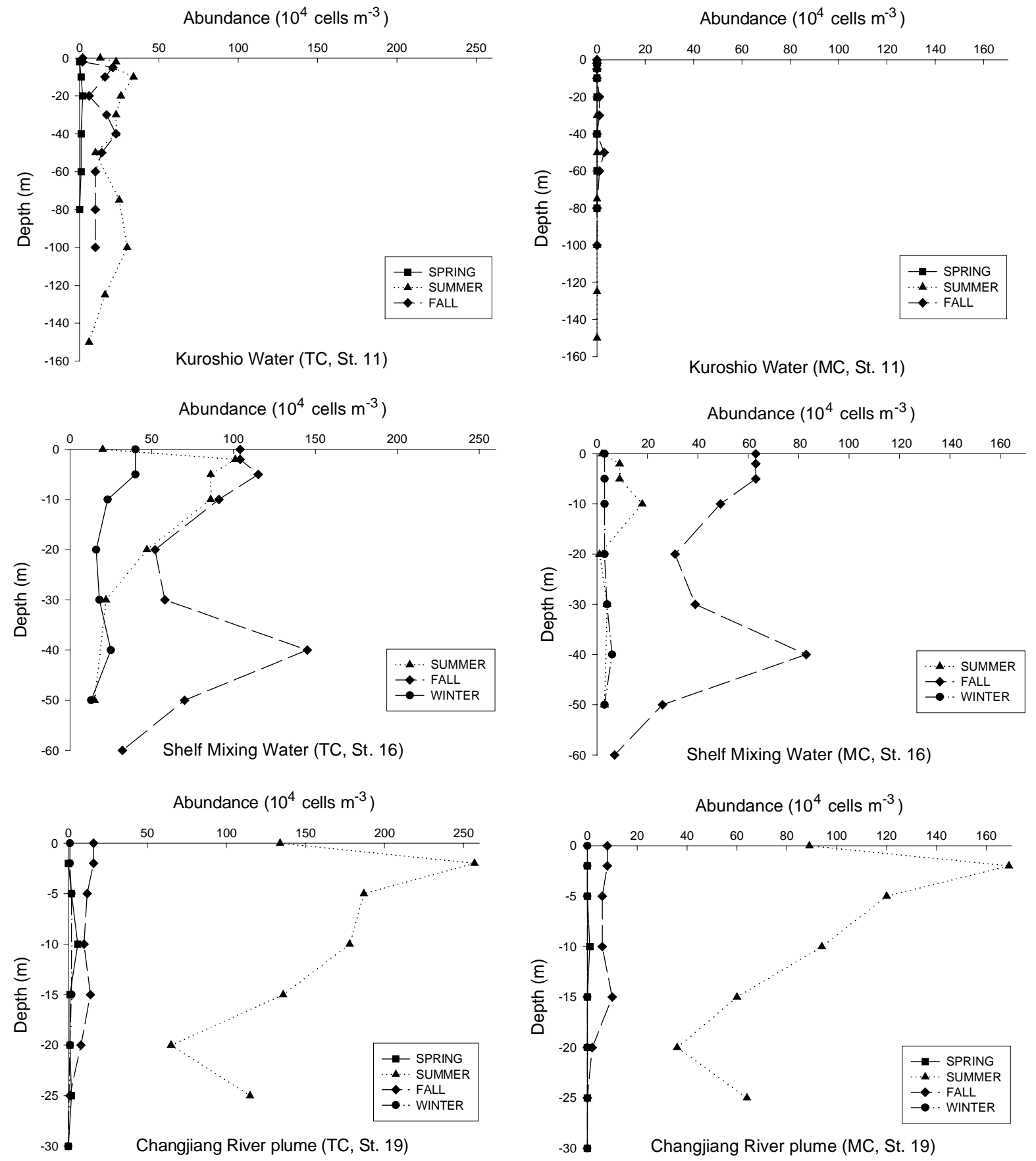

Fig. 5. Vertical distribution of TC and MC abundance $\left(\times 10^{4}\right.$ cells m$\left.^{-3}\right)$ in the ECS in Kuroshio Water (St. 11), Shelf Mixing Water (St. 16) and the Changjiang plume (St. 19) in all four seasons. 

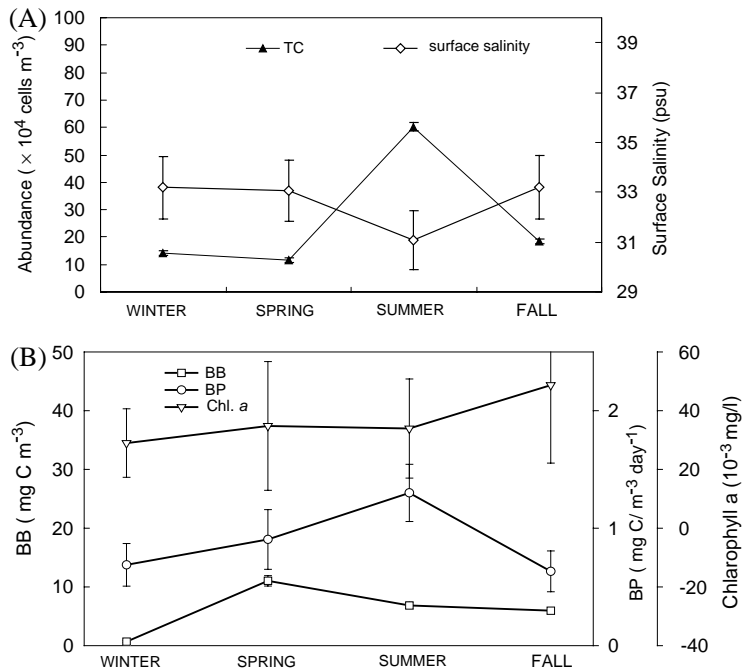

Fig. 6. Seasonal variations of (A) surface salinity and depthweighted average TC abundance $\left(\times 10^{4}\right.$ cells $\left.^{-3}\right)$; and (B) bacterial productivity (BP, $\mathrm{mg} \mathrm{C} \mathrm{m}^{-3} \mathrm{day}^{-1}$ ), bacterial biomass (BB, mg C m$\left.{ }^{-3}\right)$ and chlorophyll $a\left(\mathrm{mg} \mathrm{m}^{-3}\right)$ (BP and BB data from Shiah et al., 2000).

for MC $(P>0.05)$. However, dividing the entire study area into the Coastal Water and Shelf Mixing Water (respective definitions; see Chiang et al., 2002) indicated that most of the seasonal fluctuations could be attributed to the population dynamics in the Coastal Water (Figs. 7B and C). The increases in the summer standing stocks of $\mathrm{TC}, \mathrm{HC}$ and $\mathrm{MC}$ were, in fact, all statistically significant in the Coastal Water $(P<0.05)$, but was not true in the Shelf Mixing Water $(P>0.05)$.

\section{Discussion}

Ciliate abundance levels reported in the ECS ranged from 0.17 to $183.89 \times 10^{4}$ cells $\mathrm{m}^{-3}$. This range is similar to ciliate abundance commonly found in other oceanic ecosystems (Table 1), but the degree of variation seems higher compared to the subarctic and subtropic oceanic waters in western Pacific (Suzuki et al., 1998). Although the formaldehyde-based fixative has been shown to underestimate ciliate abundance (Leakey et al., 1994a; Stoecker et al., 1987, 1994), our results are still within the commonly accepted range, and our own test indicated similar counts from samples


Fig. 7. Seasonal variations of the depth-weighted average abundance of $\mathrm{HC}\left(\times 10^{4}\right.$ cells m$\left.^{-3}\right), \mathrm{MC}\left(\times 10^{4}\right.$ cells m$\left.^{-3}\right)$ and TC $\left(\times 10^{4}\right.$ cells m$\left.^{-3}\right)$ in (A) the entire ECS; (B) Coastal Water; and $(C)$ the Shelf Mixing Water.

fixed with formalin and with Lugol's (data not shown).

\subsection{Spatial and temporal distribution}

The ciliate distribution pattern showed a distinct variation with season. In spring and fall when Synechococcus abundance was not influenced by runoff from the Changjiang (summer) or the Yellow Sea Cold Water (winter), the ciliate and Synechococcus distributions seemed to match each other reasonably well (Chiang et al., 2002), and a positive correction could be established (Fig. 8) in the shelf area. This fact is indicative of a close coupling of Synechococcus and oligotrich ciliates in this subtropical shelf ecosystem, and it can be reasonably deduced that the coupling is caused by 


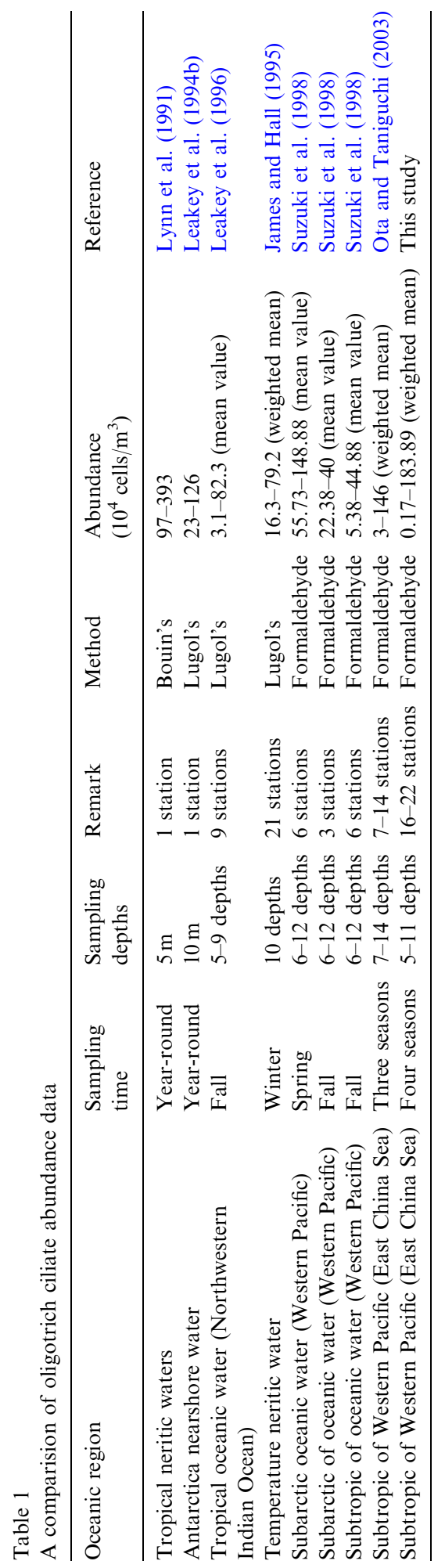

a prey-predator relation. This hypothesis is supported by Chen (2001), who reported that the grazing rate of oligotrich ciliates was controlled by Synechococcus abundance in the study area, which then had a significant influence on ciliate growth rate. In winter, the Synechococcus-ciliate relationship was disturbed when a higher Synechococcus abundance in Yellow Sea Cold water $\left(>10^{12}\right.$ cells $\mathrm{m}^{-2}$ ) was introduced into the study area (Chiang et al., 2002).

Of particular interest is that in summer, several biological processes other than Synechococcus abundance appeared to have become major controlling factors. Strong evidence suggests that the levels of terrestrial substrate had an effect on the spatial pattern of the ciliate standing stock in that period. A positive correlation between surface salinity and surface POC was noted (Fig. 9A), which strongly implies that the major source of POC was the discharge from the Changjiang. Although DOC data was not available for examination, Chiangjiang showed also brought significant amount of DOC. Furthermore, there was a good correlation between POC and BP (Fig. 9B). Shiah and Ducklow (1994) and Shiah et al. (2000) in fact have argued that this is highly indicative of the bottom-up control of bacteria. Finally, there was a positive correlation between BP and TC (Fig. 9C), suggesting that TC may be controlled by BP. We conclude from these findings that a very clear relationship exists between ciliate standing stock and the discharge of fresh water from the Changjiang (cf. Smetacek, 1981; Leakey et al., 1994b). We agree with Shiah et al. (2000) that this input of terrestrial material (i.e. POC and DOC) is in all likelihood crucial in supporting the microbial food web in the shelf water.

Ciliate standing stock in the shelf area equally displayed a distinctive temporal pattern (Fig. 6A). In temperate and polar inshore waters, planktonic ciliate populations also exhibited a clear seasonal cycle of high abundance during the spring and summer months but low abundance in the winter months, and since this cycle fully agrees with the fluctuations in chlorophyll $a$ concentration and bacterial biomass (BB) (Smetacek, 1981; Montagnes et al., 1988; Leakey et al., 1994b), a tight trophic coupling between ciliates and organic 

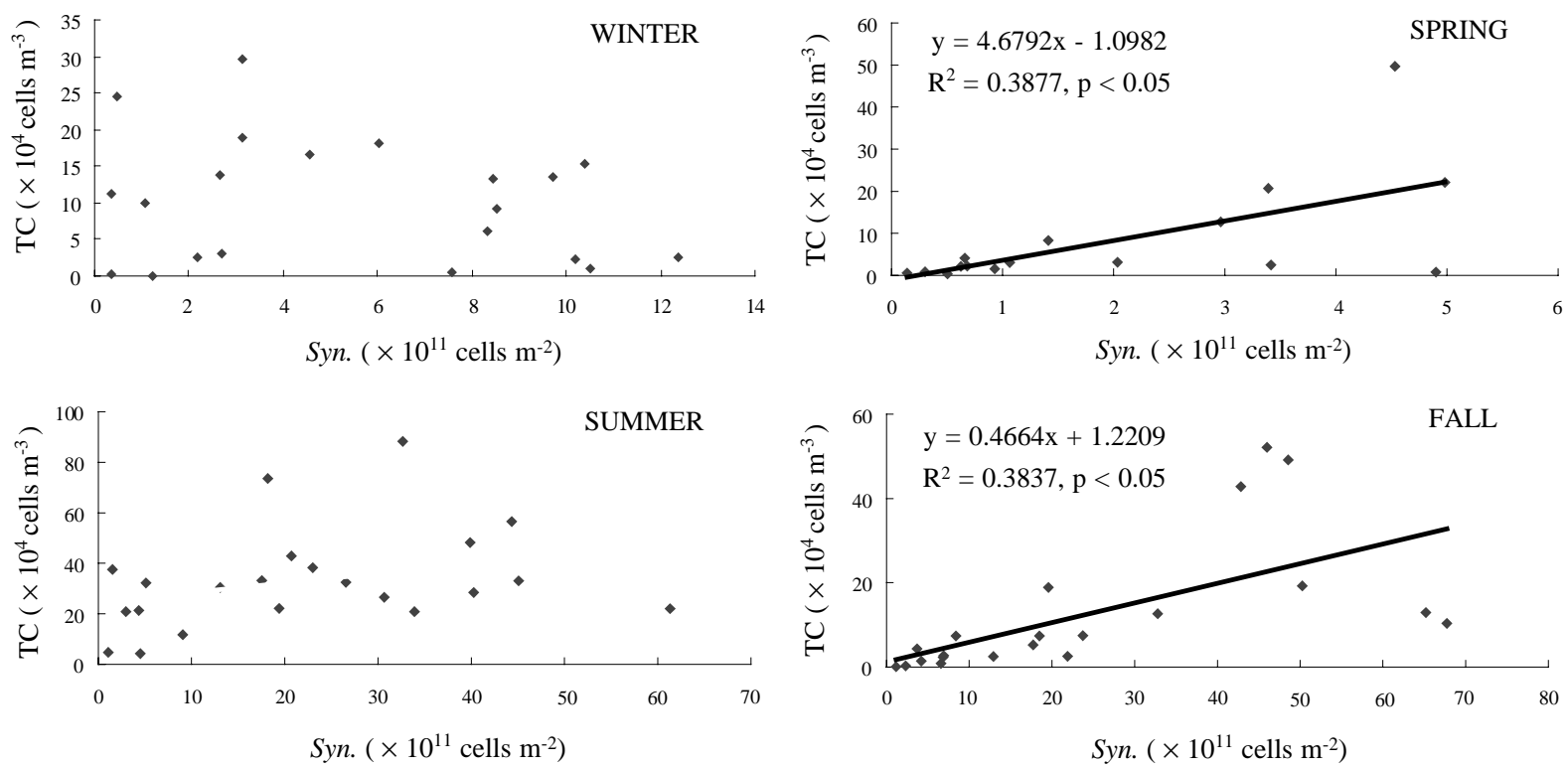

Fig. 8. Relationships between integrated Synechococcus abundance $\left(\times 10^{11}\right.$ cells $\left.\mathrm{m}^{-2}\right)$ and the depth-weighted average abundance of $\mathrm{TC}\left(\times 10^{4}\right.$ cells $\left.\mathrm{m}^{-3}\right)$ in winter, spring, summer and fall.

carbon from phytoplankton and bacteria seems quite apparent. In the ECS, it may well be that the peak ciliate population densities observed in summer were also driven by an increased availability of organic carbon, which in this case probably means bacteria rather than chlorophyll $a$ sources in light of the absence of a chlorophyll $a$ peak in summer (Fig. 6B) in the ECS. In a contemporaneous study of the ECS continental shelf area, we found that while depth-weighted average BP also did peak in summer, but the depth-weighted average $\mathrm{BB}$ reached its peak in spring (Fig. 6B), i.e. several months earlier. To explain the absence of a BB peak in summer, we suggest that a considerable amount of bacteria may have been consumed by phagoflagellates or phagociliates. This hypothesis is clearly consistent with, and helps to explain, the high summertime ciliate standing stock that was found in the present study.

\subsection{Relationship between $M C$ and phytoplankton in the Changjiang plume}

Following Gong et al. (1996) who determined salinity in the plume as $<31 \mathrm{psu}$, the summer surface salinity data along the northern transect (Transect D in Fig. 1) suggest that the center is located around at St. 20 with Sts. 19, 21 and 22 in the plume margins (Fig. 10A). Fig. 10A also shows that the abundance of total ciliates was higher within the plume region than outside it, although ciliate abundance was relatively low at the central station (St. 20). Within the plume region (but not outside it), mixotrophs made up the greatest share of the oligotrich ciliate population (Fig. 10B). Conversely, along the same transect at the same time, while the total BB remained constant, the standing stock of Synechococcous was low within the plume but it grew with increasing distance. Chang et al. (2003) also reported that the Synechococcus growth rate was 4-5 times higher within the plume than that outside it (Fig. 10D). The most likely explanation for these observations is that increased nutrient input from the Changjiang leads to an increase in Synechococcus productivity, but any increase in the abundance of these cyanobacteria is offset since Synechococcus are consumed by $\mathrm{MC}$ within the plume. The net result is, therefore, an increase in the number of MC. This hypothetical account is supported strongly by the tight relationship between $\mathrm{MC}$ and 

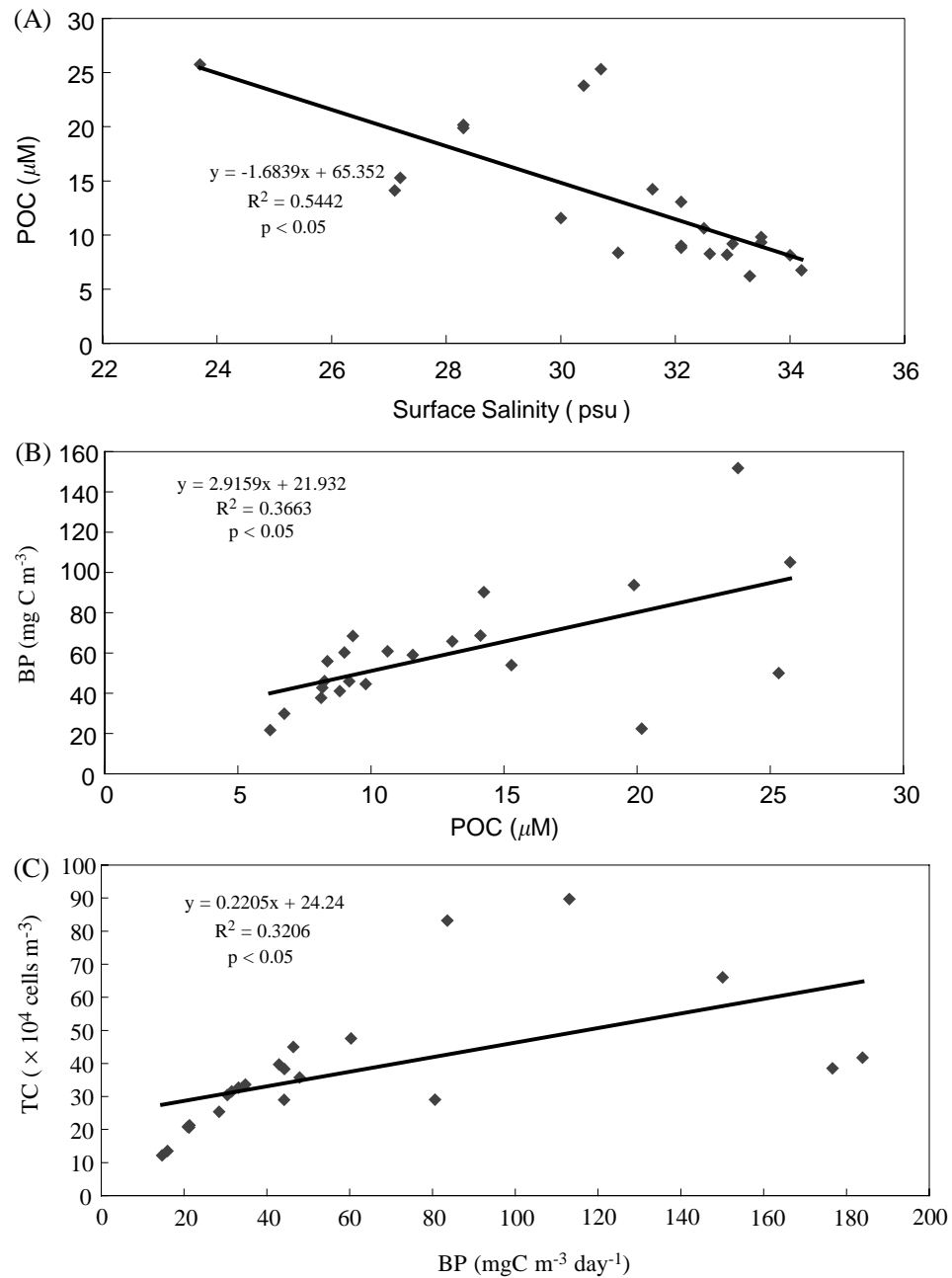

Fig. 9. Relationships between (A) surface salinity and POC; (B) POC; and BP and (C) BP and TC in summer (BP and BB data from Shiah et al., 2000).

Synechococcus abundance within the plume (but not outside it) (Fig. 11).

Some independent external evidence is available to indicate that MC and Synechococcus have a predatory/prey relationship because phycoerythrin, a pigment unique to Synechococcus (Waterbury et al., 1979), has previously been identified in some mixotrophs (McManus and Fuhrman, 1986). On the other hand, picophtoplankton is also a major food source for mixotrophic nanoflgellate (Craon, 2000). Thus, we also argue that another hypothesis may be that the great part of picophyplankton was consumed by nanoflagellate. Then these pigment-containing nanoflagellates were transported to the ciliate community. It has been proposed elsewhere that the retained plastids in MC may come from cyanobacteria (Bernard and Rassoulzadegan, 1994) or photosynthesis nanoflagellate (Craon, 2000). All of the above observations support the conclusion that the discharged fresh water of the Changjiang plume significantly affects the microbial food web in the region.

\subsection{Photosynthesis rate of $M C$ and the production of $T C$}

Putt (1990) has reported that the concentration of chlorophyll $a$ ranged from 21 to $99 \mathrm{pg} \mathrm{cell}^{-1}$ in 
(A)

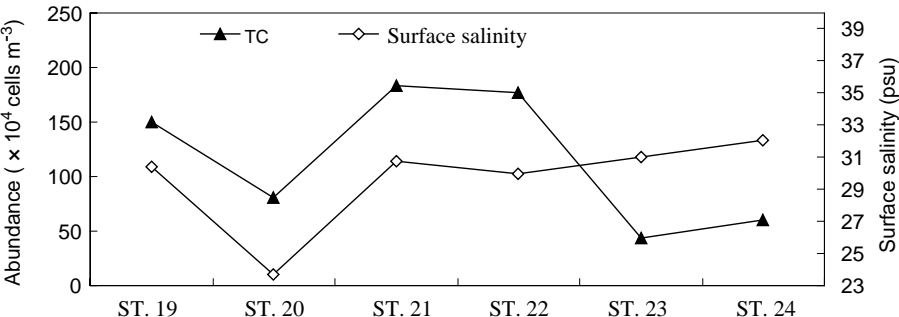

(B)

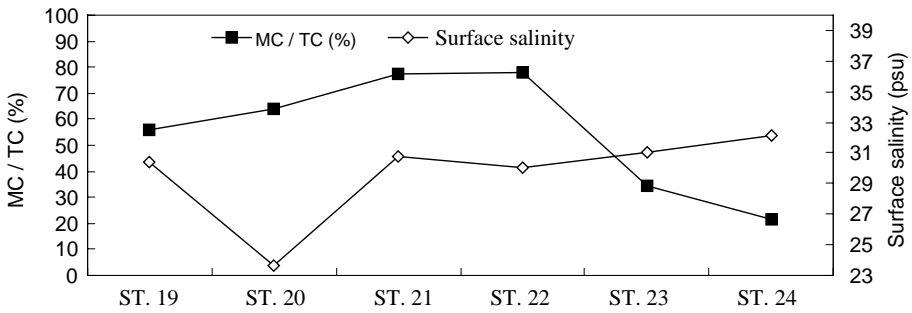

(C)



(D)

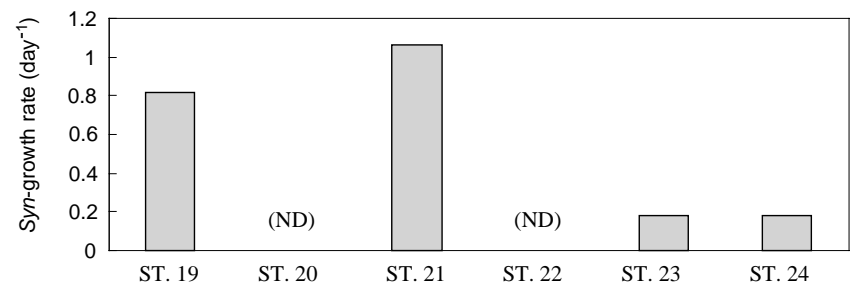

Fig. 10. Variations of (A) surface salinity (psu) and depth-weighted average abundance of TC $\left(\times 10^{4}\right.$ cells $\left.\mathrm{m}^{-3}\right)$; (B) $\mathrm{MC} / \mathrm{TC}$ ratio $(\%)$; (C) Synechococcous biomass $\left(\mathrm{mg} \mathrm{C} \mathrm{m}^{-2}\right) \mathrm{BB}\left(\mathrm{mg} \mathrm{C} \mathrm{m}^{-2}\right)$; and (D) intrinsic growth rate of Synechococcous (day $\left.{ }^{-1}\right)$ along the northern transect (Synechococcous and BB data from Shiah et al. (2000) and Chang et al. (2000), respectively).

mixotrphic oligotrich ciliates. Based on this figure, the maximum average contribution rate of MC to total chlorophyll $a$ in winter, spring, summer and fall are $0.3 \%, 1.0 \%, 2.8 \%$ and $0.7 \%$, respectively. From these results, we are confident that ciliate photosynthesis is likely negligible in the general continental shelf ecosystem of the ECS but that it does have relative importance in the Changjiang plume, where the average contribution rate is $7.7 \%$ with the highest value $(24.2 \%)$ occurring in the margin, just as seen in the high contribution rate observed in the Nordic Sea in summer $(24 \%$,
Putt, 1990). On the other hand, according to Lee (2000), the average seasonal ciliate production is 29.2 (winter), 8.8 (spring), 80.6 (summer), and $25.7 \mathrm{mg} \mathrm{C} \mathrm{m}^{-2} \mathrm{~d}^{-1}$ (fall), and the rate of ciliate carbon demand for primary production is respectively $17.8 \%, 6.5 \%, 109.7 \%$, and $25 \%$ in the ECS. From these results, we are reasonably sure that primary production cannot be sufficient to support the growth of the ciliate community in summer. It follows then that in summer, organic carbon from non-phytoplankton and allochothonous sources might play a very important role in 


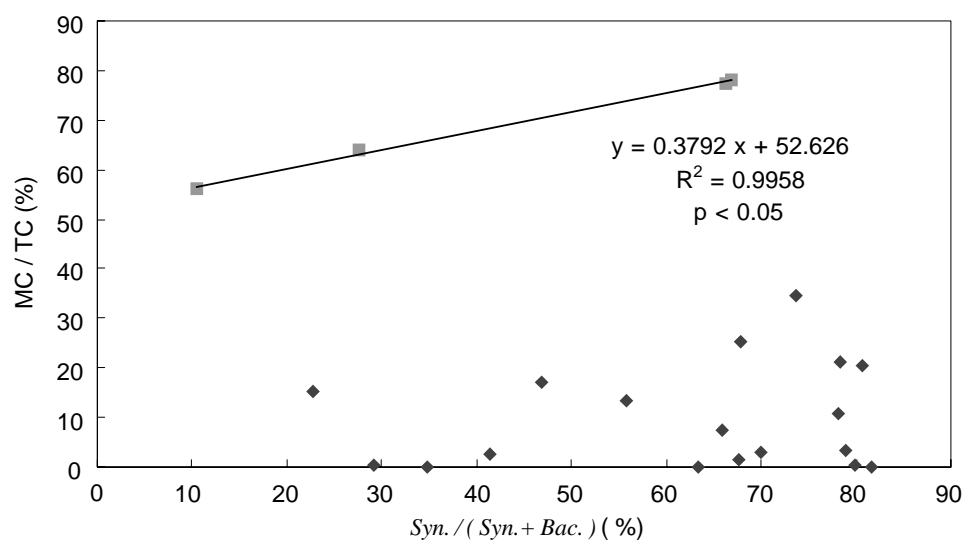

Fig. 11. Scatter plot of the contribution of Synechococcous bacteria to the microbial food web in summer: [Synechococcous/ (Bacteria + Synechococcous), \%] versus the MC/TC ratio (\%). Dark squares represent sampling stations located within the plume region (i.e. stations 19, 20, 21 and 22), Dark diamond stand for sampling station outside the plume region (Synechococcous and BB data from Shiah et al. (2000) and Chang et al. (2000), respectively).

the microbial carbon cycle in the shelf area of the ECS.

\section{Acknowledgements}

We are grateful to Dr. K.-K. Liu of National Taiwan University and Dr. G.-C. Gong of National Taiwan Ocean University for their constructive comments on this work. We also thank the officers and crewmembers of the R.V. 'Ocean Research $I$ '. This study was supported by grants from the National Science Council, ROC, NSC 89-2611-M-019-007-K2.

\section{References}

Azam, F., Fenchel, T., Field, J.G., Gray, J.S., Meyer-Reil, L.A., Thingstad, F., 1983. The ecological role of watercolumn microbes in the sea. Marine Ecology Progress Series 10, 257-263.

Beardsley, R.C., Cannon, G.A., Limeburner, R., Yu, H., 1985. Discharge of the Changjiang (Yangtze river) into the East China sea. Continental Shelf Research 4, 57-76.

Bernard, C., Rassoulzadegan, F., 1994. Seasonal variation of mixotrophic ciliates in the Northwest Mediterranean Sea. Marine Ecology Progress Series 108, 295-301.

Chang, J., Lin, K.-H., Chen, K.-M., Gong, G.-C., Chiang, K.P., 2003. Synechococcus growth and mortality rates in the East China Sea: range of variations and correlation with environmental factors. Deep-Sea Research II, this issue (doi: 10.1016/S0967-0645(03)00022-5.

Chen, L.Y.-L., 2000. Comparisons of primary productivity and phytoplankton size structure in the marginal region of the Southern East China Sea. Continental Shelf Research 20, $437-458$

Chen, K.-M., 2001. Ciliate grazing on Synechococcus in a coastal and shelf marine ecosystem: spatial-temporal variations and importance to biological carbon cycling. Ph.D. Thesis, Institute of Marine Biology, National Taiwan Ocean University, Taiwan, Republic of China, unpublished.

Chiang, K.-P., Kuo, M.-C., Chang, J., Wang, R.-H., Gong, G.C., 2002. Spatial and temporial variation of the Synechococcus population in the East China sea and its contribution to phytoplankton biomass. Continental Shelf Research 22, 3-13.

Craon, D.A., 2000. Symbiosis and Mixotrophy among pelagic microorganisms. In: Kirchman, D.L. (Ed.), Microbial Ecology of the Oceans. Wiley-Liss Inc, New York, pp. 121-152.

Fenchel, T., 1982. Ecology of heterotrophic microflagellates. IV. Quantitative occurrence and importance as bacterial consumers. Marine Ecology Progress Series 9, 35-42.

Fenchel, T., Jonsson, P.R., 1988. The functional biology of Strombidium sulcatum (Ciliophora, Oligotrichina). Marine Ecology Progress Series 48, 1-15.

Gong, G.-C., Chen, L.Y.-L., Liu, K.-K, 1996. Chemical hydrography and chlorophyll a distribution in the East China Sea in summer: implications in nutrient dynamics. Continental Shelf Research 16, 1561-1590.

Hasle, G.R., 1978. The inverted-microscope method. In: Sournia, A. (Ed.), Phytoplankton Manual. UNESCO, Paris, pp. 88-96. 
James, M.R., Hall, J.A., 1995. Planktonic ciliated protozoan: their distribution and relationship to environmental variables in a marine coastal ecosystem. Journal of Plankton Research 17, 659-683.

Laybourn-Parry, J., 1992. Protozoan Plankton Ecology. Chapman \& Hall, London, UK, 231pp.

Leakey, R.J.G., Burkill, P.H., Sleigh, M.A., 1994a. A comparison of fixatives for the estimation of abundance and biovolume of marine planktonic ciliate populations. Journal of Plankton Research 16, 375-389.

Leakey, R.J.G., Fenton, N., Clarke, A., 1994b. The annual cycle of planktonic ciliates in Nearshore waters at Signy Island, Antarctica. Journal of Plankton Research 16, 841-856.

Leakey, R.J.G., Burkill, P.H., Sleigh, M.A., 1996. Planktonic ciliates in the northwestern Indian Ocean: their abundance and biomass in waters of contrasting productivity. Journal of Plankton Research 18, 1063-1071.

Lee, C.-H., 2000. Studies on biomass, production and carbon contribution of oligotrich ciliates in the East China Sea. Masters Thesis, Institute of Fishery Science, National Taiwan Ocean University, Taiwan, Republic of China, unpublished.

Lynn, D.H., Roff, J.C., Hopcroft, R.R., 1991. Annual abundance and biomass of aloricate ciliates in tropical neritic waters off Kingston, Jamaica. Marine Biology 110, 437-448.

Marshall, S.M., 1973. Respiration and feeding in copepods. Advances in Marine Biology 11, 57-120.

McManus, G.B., Fuhrman, J.A., 1986. Photosynthetic pigment in the ciliate Laboea strobila from Long Island Sound, USA. Journal of Plankton Research 8, 317-327.

Montagnes, D.J.S., Lynn, D.H., Roff, J.C., Taylor, W.D., 1988. The annual cycle of heterotrophic planktonic ciliates in the waters surrounding the Isles of Shoals, Gulf of Maine: an assessment of their trophic role. Marine Biology $99,21-30$.

Ota, T., Taniguchi, A., 2003. Standing crop of planktonic ciliates in the East China Sea and their potential grazing impact and contribution to nutrient regeneration. Deep-Sea Research II 50, 423-442.

Pomeroy, L.R., 1974. The ocean's food web, a changing paradigm. BioScience 24, 499-504.
Putt, M., 1990. Abundance, chlorophyll content and photosynthesis rates of ciliates in the Nordic Sea during summer. Deep-Sea Research I 37 (11), 1713-1731.

Sherr, E.B., Sherr, B.F., 1987. High rates of consumption of bacteria by pelagic ciliates. Nature 325, 710-711.

Sherr, E.B., Sherr, B.F., Mcdaniel, J., 1991. Clearance rates of $<6 \mu \mathrm{m}$ flourescently labeled algae (FLA) by estuarine protozoa: potential impact of flagellates and ciliates. Marine Ecology Progress Series 69, 81-92.

Shiah, F.-K., Ducklow, H.W., 1994. Temperature regulation of heterotrophic bacterioplankton abundance, production, and specific growth rate in Chesapeake Bay. Limnology and Oceanography 39 (6), 1243-1258.

Shiah, F.-K., Liu, K.-K., Kao, S.-J., Gong, G.-C., 2000. The coupling of bacterial production and hydrography in the Southern East China Sea: spatial patterns in spring and fall. Continental Shelf Research 20, 459-477.

Shiomoto, A., Tadokoro, K., Monaka, K., Nanba, M., 1997. Productivity of picoplankton compared with that of larger phytoplankton in the Subarctic region. Journal of Plankton Research 19, 907-916.

Smetacek, V., 1981. The annual cycle of protozooplankton in the Kiel Bight. Marine Biology 63, 1-11.

Song, W., Zhu, M., Chen, Z., 1999. Updating the systematics of the planktonic oligotrichous ciliates (Ciliophora, Protozoa) with description of ciliature patterns at generic level. The Journal of International Society of Yellow Sea Research 5, 77-85.

Stockner, J.G., Antia, N.J., 1986. Algal picoplankton from marine and freshwater ecosystems: a multidisciplinary perspective. Canadian Journal of Fisheries and Aquatic Science 43, 2472-2503.

Stoecker, D.K., Michaels, A.E., Davis, L.H., 1987. Large proportion of marine planktonic ciliates found to contain functional chloroplasts. Nature 326, 790-792.

Stoecker, D.K., Gifford, D.J., Putt, M., 1994. Preservation of marine planktonic ciliates: losses and cell shrinkage during fixation. Marine Ecology Progress Series 110, 293-299.

Suzuki, T.N., Yamada, N., Taniguchi, A., 1998. Standing crops of planktonic ciliates and nanoplankton in oceanic waters of the Western Pacific. Aquatic Microbial Ecology 14, 49-58.

Waterbury, J.B., Watson, S.W., Guillard, R.R., Brand, L.E., 1979. Widespread occurrence of a unicellular marine planktonic cyanobacterium. Nature 277, 293-294. 